\title{
EVALUATION OF FERMENTED FISH OFFAL IN FORMULATED DIET OF THE INDIAN MAJOR CARP, ROHU, LABEO ROHITA (HAMILTON)
}

\author{
Kausik MONDAL ${ }^{1}$, Anilava KAVIRAJ ${ }^{1 *}$, Pratap Kumar MUKHOPADHYAY ${ }^{3}$, \\ Moumita DATTA ${ }^{2}$, and Chandan SENGUPTA ${ }^{2}$ \\ ${ }^{1}$ Department of Zoology, ${ }^{2}$ Department of Botany, University of Kalyani, Kalyani, West Bengal, India \\ ${ }^{3}$ Wastewater Aquaculture Division, Central Institute of Freshwater Aquaculture, P.O. Rahara, Kolkata, \\ West Bengal, India
}

Mondal K., Kaviraj A., Mukhopadhyay P.K., Datta M., Sengupta C. 2007. Evaluation of fermented fish offal in formulated diet of the Indian major carp, rohu, Labeo rohita (Hamilton). Acta Ichthyol. Piscat. 37 (2): 99-105.

Background. Carp fish offal contains high amount of protein and lipid. The quest for protein sources alternative to fish meal has been a priority in aquaculture research because of growing concerns on the future availability of fish meal for incorporation in fish diets. This study determined the extent to which carp fish offal could be fermented and used to replace fish meal in the formulation of diet for fingerlings of Labeo rohita.

Materials and Methods. Fish offal, comprising viscera of carp, was fermented along with mustard oil cake and rice bran anaerobically by a microbial suspension $\left(10^{8}\right.$ cells $\left.\cdot \mathrm{mL}^{-1}\right)$ under ambient temperature $\left(27-30^{\circ} \mathrm{C}\right)$. The fermented mixture was mixed with fish meal, mineral- and vitamin mixture to prepare three experimental diets: 1) a reference diet (T1), without any fermentation mixture, containing $40 \%$ fish meal, 2 ) a diet containing $25 \%$ fish offal (fermented) and $25 \%$ fish meal (T2), and 3) a diet containing 30\% fish offal (fermented) and 20\% fishmeal (T3). These diets were tested to evaluate growth and biochemical composition of the body of the fingerlings of Labeo rohita and apparent protein digestibility (APD) and intake rate of the diets by the fish. Proximate analysis of feed ingredients, experimental diets, faecal samples and the carcass were performed following the AOAC procedures.

Results. Fingerlings of Labeo rohita, reared for 60 days with the diets containing fermented fish offal mixture (T2 and T3), showed higher growth and higher values of protein and lipid in the carcass than those reared with the reference diet (T1). Apparent protein digestibility of the diets did not vary significantly, but average feed intake rate of the $\mathrm{T} 2$ and $\mathrm{T} 3$ diets were higher than the $\mathrm{T} 1$ diet.

Conclusions. Fermented fish offal is a viable alternative of fish meal in the formulation of diet for fingerlings of Labeo rohita. Fifty percent replacement of fish meal is possible by a mixture containing $30 \%$ fish offal. Further studies are required to improve quality of the fermentation mixture and increase the rate of replacement of fish meal.

Keywords: fish offal, recycling, fishmeal, protein, growth, rohu, Labeo rohita

\section{INTRODUCTION}

There has been a considerable research effort towards utilization of less expensive renewable ingredients in fish diet formulations to alleviate problems related to shortage of quality fish meal (Pongmaneerat et al. 1993, El Sayed 1994, Rangacharyulu et al. 2003, Yang et al. 2004, Mukhopadhyay and Mitra 2007). Fish offal, which is generated in large quantities on a daily basis in the urban and sub-urban markets in India, has immense potential to be used as a predominant nutrient source in fish diet formulations. Very few studies have evaluated its efficacy, so far (Giri et al. 2000). In a preliminary investigation we observed the viscera of carps, which are discarded in bulk as offal in the retail fish markets contain a substantial amount of crude protein $(31.5 \%-38.9 \%)$ and lipid $(40.6 \%-43.8 \%)$ on a dry matter basis (Mondal et al. 2006). Collection of these wastes from the urban and suburban markets, treating them suitably to preserve their nutrients and finally recycling them into fish diet production can have a significant benefit in terms of abatement of pollution of environment as well as reduction in the recurring cost of fish production.

Although dried fish, chicken viscera, and related animal by-products have been evaluated previously as protein resource in fish diet formulations (Saha and Ray 1998, Giri et al. 2000), efficacy of fish offal as such has not been

\footnotetext{
* Correspondence: Prof. Anilava Kaviraj, Department of Zoology, University of Kalyani, Kalyani-741235, West Bengal, India, phone: +9133-25828478, fax: +9133-25828282, e-mail: anilava@vsnl.net
} 
ascertained as nutrient sources probably because of inherent difficulties in handling it either in dried or in raw condition. While drying of the offal results in considerable loss of the nutrients, its direct use leads to rapid spoilage of the whole diet. In the present study an attempt was made to evaluate if fish offal (FO) could be fermented and used to replace fish meal (FM) in the preparation of formulated fish diet. The process of fermentation or composting is widely employed in fish diet formulation to decrease the anti-nutritional factors and crude fibre content of plant diet stuff (Ray and Das 1992, Bairagi et al. 2002). The process of fermentation improves nutritional quality of animal product also. Rangacharyulu et al. (2003) observed that fermented silk worm pupae silage (SWP) was nutritionally superior to untreated SWP or fishmeal. Bertsch and Coello (2005) used a strain of keratinolytic bacteria to ferment poultry feather and obtained poultry feather meal with $71 \%$ crude protein and improved bioavailability of some amino acids. The objective of this study was to determine the extent to which fish offal could replace fish meal in carp (Labeo rohita) diet while maintaining nutritional quality almost identical to the diet based on fish meal and thus be an ideal cost effective renewable alternative.

\section{MATERIALS AND METHODS}

Experimental diet formulation and preparation. Three diets were prepared with mustard oil cake (MOC), rice bran (RB), fish meal, and fish offal. The fish offal, comprising viscera of cultured carps (Labeo rohita and Catla catla), was obtained from the local retail fish markets. The portion of guts contained in the offal was carefully uncoiled, cut open and the gut contents were removed using clean water. Fresh samples of fish offal were used for diet preparation. Ingredient constituents and proximate composition of the diets have been given in Table 1. The feeds were formulated in such a way that these contained not less than $30 \%$ crude protein. The reference diet (T1) was prepared using $40 \%$ fish meal, by weight, while two other diets (T2 and T3) were prepared by partially replacing fishmeal with fermented fish offal (Table 1). For fermentation, the fish offal, mustard oil cake, and rice bran were mixed and the mixture was added to a solution of microbial suspension $\left(10^{8}\right.$ cell $\left.\cdot \mathrm{mL}^{-1}\right)$ (the microbial suspension $\left(\mathrm{EM}^{\mathrm{TM}}\right)$ was a gift from M/S, Maple Orgtech Pvt. Ltd. Mumbai.), molasses and water $(2.5 \mathrm{~mL}: 2.5 \mathrm{~g}: 100 \mathrm{~mL})$ and was fermented anaerobically under ambient temperature $\left(27-30^{\circ} \mathrm{C}\right)$ for 12 to 22 days, depending on the pro-

Table 1

Formulation and proximate analyses of the experimental diets

\begin{tabular}{|c|c|c|c|c|}
\hline & \multirow[b]{2}{*}{ Contents } & \multicolumn{3}{|c|}{ Diet } \\
\hline & & $\begin{array}{c}\mathrm{T} 1 \\
\text { (Reference) }\end{array}$ & Т 2 & $\mathrm{~T} 3$ \\
\hline \multirow{6}{*}{ 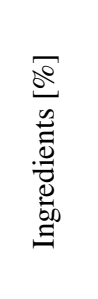 } & Mustard oil cake & 29 & 24 & 24 \\
\hline & Rice bran & 29 & 24 & 24 \\
\hline & Fish offal & - & 25 & 30 \\
\hline & Fishmeal & 40 & 25 & 20 \\
\hline & Vitamin premix $^{1}$ & 01 & 01 & 01 \\
\hline & Mineral premix ${ }^{2}$ & 01 & 01 & 01 \\
\hline \multirow{7}{*}{ 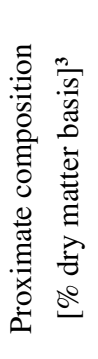 } & Protein & 32.5 & 31.4 & 30.2 \\
\hline & Lipid & 4.5 & 9.2 & 11 \\
\hline & Moisture & 7 & 6 & 8 \\
\hline & Ash & 15 & 13.5 & 12 \\
\hline & Dry matter & 93 & 94 & 92 \\
\hline & Gross Energy $\left[\mathrm{kJ} \cdot \mathrm{g}^{-1}\right]^{4}$ & 15.34 & 16.69 & 16.93 \\
\hline & $\mathrm{P}: \mathrm{E} \mathrm{ratio}^{5}$ & 21.19 & 18.82 & 17.85 \\
\hline
\end{tabular}

${ }^{1}$ Vitamin mixture [\%]: (Ambiplex; Brihans Lab, Pune): vit B1: 7.14, vit B2: 2.55, vit B6: 1.02, vit B12: 0.012, biotin: 0.025 , calcium pantothenate: 2.55 , niacin: 76.50 , cholin chloride (B4): 10.20 ; vitamin $\mathrm{C}$ in the form of ascorbyl polyphosphate was added to vitamin mixture at $100 \mathrm{mg} \cdot \mathrm{kg}^{-1}$ mixture.

${ }^{2}$ Mineral mixture [\%]: (Agrimin; Glaxo India Ltd, Mumbai) copper: 3.12, cobalt: 0.45, magnesium: 21.14, iron: 9.79, iodine: 1.56 , zinc: 21.30 , calcium: 30.00 , phosphorus: 8.25 .

3 Number of samples per each determination $=3$.

${ }^{4}$ Gross energy was calculated on the basis of methodology of Brafield (1985).

5 Protein to total energy ratio $\left[\mathrm{mg} \cdot \mathrm{kJ}^{-1}\right]$. 
portion of fish offal. Based on a preliminary evaluation, $30 \%$ fish offal was determined as the maximum level for fermentation by the microbial suspension. Unfermented fish offal putrefied and became unsuitable for use in diet formulation. Samples of fermentation mixture were taken from each level of trial fermentation and were analyzed for aroma, physical condition, total nitrogen, organic carbon, and bacterial population count every 6 days till the end of fermentation. Final fermented product (T2: 19.2\% of crude protein, $7.8 \%$ of crude lipid, and $10.2 \%$ of ash; T3: $20.7 \%$ of crude protein, $9.9 \%$ of crude lipid, and $9.4 \%$ of ash) was mixed with fish meal, vitamin, and mineral mixture in proportion so that one mixture contained $25 \%$ fish meal (T2) and the other contained $20 \%$ fish meal (T3). The mixtures were ground and pelleted using a hand pelletizer fitted with a 2-mm dia to prepare the final experimental diets (Table 1). To test the protein digestibility of the diet, 1-\% chromic oxide $\left(\mathrm{Cr}_{2} \mathrm{O}_{3}\right)$ was included in each diet separately as non-absorbed reference substance, blended, and pelleted with $0.5 \%$ carboxymethyl cellulose as a binder. This was sun dried before using in the feeding trial.

Feeding trials. Two experimental systems were utilized for the feeding trials: one in outdoor cement tanks $(400 \mathrm{~L})$ to evaluate growth and biochemical composition of the body, and the other in indoor glass aquaria $(50 \mathrm{~L})$ to evaluate voluntary diet intake and apparent protein digestibility (APD). Deep tube-well water stored in an overhead tank was used in the feeding trial. Fingerlings of rohu (mean initial length $4.65 \pm 0.19 \mathrm{~cm}$ and mean initial weight $0.98 \pm 0.17 \mathrm{~g}$ ) were obtained from a local fish farm and were acclimatized to the laboratory conditions for a week prior to start of the experiment. The fingerlings were fed to satiation (twice a day six days a week) with the reference diet (T1) during acclimatization. The acclimatized fingerlings were randomly distributed at the rate of 40 pieces per tank and 10 per aquarium. The water temperature in aquarium ranged from $21-24^{\circ} \mathrm{C}$ and aeration was provided to maintain a dissolved oxygen level of approximately $6-7 \mathrm{mg} \cdot \mathrm{L}^{-1}$. The tanks or aquaria were laid out in a completely randomized block design (Gomez and Gomez 1984) with three replicates for each of the three diet treatments.

For the feeding trial in outdoor tanks all fish were fed twice daily at $1000 \mathrm{~h}$ and $1600 \mathrm{~h}$ at a fixed feeding rate of $5 \%$ body weight per day for the entire experimental period of 60 days. The quantity of the diet given was readjusted every 15 days after weighing the fish. Samples of water were collected every week to determine selected parameters like dissolved oxygen, free carbon dioxide, total ammonia, alkalinity, hardness, and $\mathrm{pH}$-following the APHA procedures (Anonymous 1995). All fish from each outdoor tank were sampled at the end of 60 days trial and their length and weight were recorded. Five fish sampled from each tank were randomly selected and were frozen at $-20^{\circ} \mathrm{C}$. Biochemical analyses, to determine crude protein, crude lipid, and ash content of the carcass, were done on pooled fish samples from each tank, giving a total of three samples for each diet. Increase in length and weight, spe- cific growth rate (SGR), food conversion ratio (FCR), protein efficiency ratio (PER), and apparent net protein utilization (ANPU) were calculated using standard methods (Castell and Tiews 1980). For the trial in glass aquaria same ration of diet was given to the fish and the fish were allowed to eat for $6 \mathrm{~h}$. Left-over diet, if any, was collected after $6 \mathrm{~h}$ of feeding, oven dried, weighed, and stored frozen at $-20^{\circ} \mathrm{C}$. Faecal samples were collected from each aquarium in the morning by careful siphoning, dried in an oven at $60^{\circ} \mathrm{C}$, and weighed before preserving at $-20^{\circ} \mathrm{C}$. The feeding trial lasted for 10 days. Pooled samples of diet and faeces from each aquarium were digested, using a mixture of sulphuric acid and perchloric acid, as described by Bolin et al. (1952), and chromium contents in the samples were determined by flame atomic absorption spectrophotometer (Varian Spectra AA240), according to Kaviraj and Ghosal (1998). Apparent protein digestibility (APD) values of the diets were calculated from the proportion of $\mathrm{Cr}$ and protein in the diet and faeces (Fontaínhas-Fernandes et al. 1999).

Analytical procedures. Total nitrogen and organic carbon of the fermentation mixture were determined by AOAC procedures (Helrich 1990). The bacterial colonyforming unit (CFU) was isolated by serial dilution, plating, and incubation, as outlined in Atlas et al. (1995). Proximate analyses of the feed ingredients, experimental diets, carcass and faecal samples were performed following the AOAC procedures (Helrich 1990) as follows: moisture was determined by oven drying at $105^{\circ} \mathrm{C}$ for $24 \mathrm{~h}$; crude protein (nitrogen $\times 6.25$ ) was determined by Kjeldahl method, after acid hydrolysis; lipid was extracted by petroleum ether (boiling point $40-60^{\circ} \mathrm{C}$ ) for $7-8 \mathrm{~h}$ in a Soxhlet apparatus followed by determination of lipid gravimetrically and ash was determined by combustion at $550^{\circ} \mathrm{C}$, in a muffle furnace, till a constant weight. Water quality parameters were determined during the outdoor feeding trial by the procedures of APHA (Anonymous 1995).

Statistical analyses. The nature of distribution of the observations of each response variable from both the trials was verified by Kolmogorov-Smirnov $(\mathrm{K}-\mathrm{S})$ and Shapiro-Wilks (S-W) tests to ensure a Gaussian distribution. Since all data were found normally distributed they were subjected to Single factor ANOVA, without any further transformation, followed by least significant difference (LSD) test to compare mean between the treatments (Gomez and Gomez 1984, Johnson and Wichern 2005).

\section{RESULTS}

Completion of fermentation was indicated by the generation of a characteristic pleasant aroma, which appeared on the 12th day for the $25 \%$ FO (fish offal) mixture and on 18th day for the $30 \%$ FO mixture (T3, Table 1). Organic carbon content of the T2 mixture gradually reduced from $12.02 \mathrm{mg} \cdot \mathrm{g}^{-1}$ at day 1 to $8.4 \mathrm{mg} \cdot \mathrm{g}^{-1}$ on day 12 and remained unaltered thereafter, while in $\mathrm{T} 3$ mixture it reduced from $13.5 \mathrm{mg} \cdot \mathrm{g}^{-1}$ to $11.6 \mathrm{mg} \cdot \mathrm{g}^{-1}$ on day 12 and continued to reduce further and became unaltered at $8.5 \mathrm{mg} \cdot \mathrm{g}^{-1}$ only after 22 days. A similar trend 
was noted for total nitrogen. $\mathrm{pH}$ of the fermented mixture gradually decreased from an initial value of 8.0-8.2 to 4.4-4.6. Two distinct bacterial colonies were detected in the bacterial culture of the fermentation mixture. One grew only in the mixture containing the microbial suspension and the other appeared in both the mixtures, irrespec- of water recorded during the outdoor trial showed values in optimum range required for rearing carp fingerlings (Table 4). There was no significant difference in the apparent protein digestibility among different dietary treatments. But voluntary intake rate of the T2 and T3 diets were significantly higher than the $\mathrm{T} 1 \operatorname{diet}$ (Table 2).

Table 2

Digestibility, diet intake, growth performance, and diet efficiency of Labeo rohita fingerlings, fed experimental diets; data are mean \pm standard deviation $(n=15)$; means with dissimilar superscripts in the same row indicate significant difference (LSD) between the means at 5\% level

\begin{tabular}{lccc}
\hline & \multicolumn{2}{c}{ Diet } \\
\cline { 2 - 4 } Parameter & T 1 & & T3 \\
& (Reference) & T 2 & $88.8 \pm 1.98$ \\
\hline APD $^{1}[\%]$ & $90.1 \pm 0.14$ & $86.2 \pm 3.96$ & $4.73^{\mathrm{b}} \pm 0.08$ \\
Diet intake [g per 100 g BW per d] & $3.75^{\mathrm{a}} \pm 0.08$ & $4.34^{\mathrm{b}} \pm 0.06$ & $38.30^{\mathrm{b}} \pm 0.94$ \\
Length increase & $22.56^{\mathrm{a}} \pm 1.18$ & $34.00^{\mathrm{b}} \pm 7.02$ & $179.57^{\mathrm{b}} \pm 13.38$ \\
Weight increase & $76.40^{\mathrm{a}} \pm 6.35$ & $167.27^{\mathrm{b}} \pm 30.78$ & $1.13^{\mathrm{b}} \pm 0.08$ \\
FCR $^{2}$ & $2.90^{\mathrm{a}} \pm 0.97$ & $1.24^{\mathrm{b}} \pm 0.24$ & $1.75^{\mathrm{b}} \pm 0.15$ \\
SGR $^{3}[\%$ per d] & $0.86^{\mathrm{a}} \pm 0.25$ & $1.51^{\mathrm{b}} \pm 0.43$ & $1.83^{\mathrm{b}} \pm 0.08$ \\
PER $^{4}$ & $1.00^{\mathrm{a}} \pm 0.07$ & $1.74^{\mathrm{b}} \pm 0.21$ & $33.92^{\mathrm{b}} \pm 2.37$ \\
ANPU $^{5}$ & $14.31^{\mathrm{a}} \pm 1.56$ & $32.20^{\mathrm{b}} \pm 4.81$ & \\
\hline
\end{tabular}

${ }^{1} \mathrm{APD}=100-100 \times(\% \mathrm{Cr}$ in diet $/ \% \mathrm{Cr}$ in faeces $) \times(\%$ protein in faeces $/ \%$ protein in diet $)$.

${ }^{2} \mathrm{FCR}=$ dry weight of diet given $/$ increase in weight of the fish.

${ }^{3} \mathrm{SGR}=((\ln$ final weight $-\ln$ initial weight $) /$ days on trial $) \times 100$.

${ }^{4} \mathrm{PER}=$ wet weight gain of fish $/$ protein consumed.

${ }^{5} \mathrm{ANPU}=$ (net increase in carcass protein / amount of protein consumed $) \times 100$.

tive of its association with the microbial suspension, indicating that the former was contributed by the microbial suspension, while the later was the native flora of the offal. The former colony started growing from 6 days of fermentation and reached a peak on the 12 th day $\left(40 \times 10^{3}\right.$ $\mathrm{CFU} \cdot \mathrm{g}^{-1} \mathrm{FO}$ ) in the $\mathrm{T} 2$ mixture and on the 22 nd day $\left(96 \times 10^{3} \mathrm{CFU} \cdot \mathrm{g}^{-1} \mathrm{FO}\right)$ in the $\mathrm{T} 3$ mixture.

The survival rate of the fingerlings during growth trial in outdoor tanks ranged from $90 \%$ to $95 \%$ and showed no significant variation between the dietary treatments. Survival rate of the fingerlings during digestibility trial in indoor aquaria was $100 \%$, irrespective of treatments. Fingerlings reared in outdoor tanks with T2 and T3 diets showed significantly higher growth (increase in length, weight, and specific growth rate) than the reference diet (T1) (Table 2). Food conversion ratio (FCR), Protein Efficiency Ratio (PER), and Average Net Protein Utilization (ANPU) also showed similar trends. There was no significant difference of any parameters evaluated between T2 and T3 diets. Proximate composition of the carcass at the end of the trial also showed significantly higher value of crude protein and lipid in T2 and T3 as compared to $\mathrm{T} 1$ diet (Table 3). Temperature, $\mathrm{pH}$, dissolved oxygen, free carbon dioxide, total alkalinity, and hardness

\section{DISCUSSION}

The present results indicate that the high amount of crude protein and lipid present in the FO can be utilized in carp diet formulation if it is fermented with suitable microorganisms. FO could be used up to $30 \%$ and with the microbial suspension used in the present study it required 22 days for complete fermentation. Further research is necessary to increase the efficiency of fermentation with specific strains of bacteria.

It has been reported that optimum protein requirement of Indian major carps ranges between $30 \%$ and $45 \%$ (Renukardhya and Varghese 1986, Mohanty et al. 1990). However, concentrating on level of crude protein alone may be misleading in formulation of practical diet for fingerlings of Labeo rohita since fishes generally regulate their feed intake in relation to the energy content of the diet. The dietary energy level, particularly lipid to carbohydrate ratio, not only affects the growth and body composition of fish but also affects its digestive enzyme activity and plasma concentration (Ali and Jauncey 2005). Garling and Wilson (1977) observed that fish fed higher level of dietary lipid exhibited higher liver protease activity. Ray and Das (1992) observed that fingerlings of Labeo rohita fed a diet containing composted weed (20\%) 
Table 3

Proximate composition of carcass [\% dry weight] determined from pooled sampled of fish $(n=5)$ from each tank; data are mean of three replicates \pm standard deviation; different superscript letters in a row indicate significant difference between treatments (LSD, $P<0.05$ )

\begin{tabular}{lrrrr}
\hline \multirow{2}{*}{ Component } & \multicolumn{3}{c}{ Initial } & \multicolumn{3}{c}{ Final } \\
\cline { 2 - 4 } & & \multicolumn{1}{c}{ T1 } & \multicolumn{1}{c}{ T2 } \\
\hline Crude protein & $39.2 \pm 0.53$ & $42.55^{\mathrm{a}} \pm 0.21$ & $46.6^{\mathrm{b}} \pm 0.2$ & $48.6^{\mathrm{c}} \pm 0.2$ \\
Crude lipid & $14.6 \pm 0.28$ & $16.3^{\mathrm{a}} \pm 0.14$ & $19.7^{\mathrm{b}} \pm 0.14$ & $18.7^{\mathrm{c}} \pm 0.14$ \\
Ash & $14.3 \pm 0.14$ & $18.5^{\mathrm{a}} \pm 0.14$ & $18.7^{\mathrm{a}} \pm 0.14$ & $19.3^{\mathrm{b}} \pm 0.14$ \\
\hline
\end{tabular}

and fish meal (80\%) with $30.72 \%$ crude protein showed higher growth than those reared with a diet containing only fish meal (100\%) with $35.7 \%$ protein. In the present study the crude protein level in the diet ranged from $30.2 \%$ in $\mathrm{T} 3$ diet to $32.5 \%$ in the $\mathrm{T} 1$ diet. Interestingly, best growth was obtained in fish fed the diet containing the lowest level of crude protein $(30.2 \%, \mathrm{~T} 3)$. This diet contained the highest level of lipid.

In any fish feeding trial, acceptability of the diet (Hasan et al. 1997) and digestibility of the nutrients (Cho and Kaushik 1990) are crucial factors besides source of protein (Kaushik et al. 1995), fat (Guillou et al. 1995) and dietary fat content (Bjerkeng et al. 1997) that can have profound influence on the growth and flesh quality of fish. In the present study, voluntary intake rate of the diet containing FO (25\% and 30\%) was significantly higher than the reference diet (T1) containing $40 \%$ fish meal. The rate of diet intake by fingerlings of Labeo rohita observed in the present investigation (3.75 to $4.73 \mathrm{~g}$ per $100 \mathrm{~g} \mathrm{BW}$ per day) was higher than the rate observed by Bairagi et al. (2002) for a reference diet containing $40 \%$ fish meal and diets containing different levels of duckweed leaf meal. In addition to ambient water quality condition, quality of the ingredients play crucial role in voluntary intake of a formulated diet. Gomes et al. (1995) observed depression in voluntary diet intake of rainbow trout when fishmeal was totally replaced by vegetable protein. But no such depression was found in tilapia fed $100 \%$ vegetable protein. The three diets used in the present investigation did not show any significant difference in the protein digestibility, which varied from 86.2 to $90 \%$. Although protein digestibility generally increases with the levels of dietary protein (Ali and Jauncey 2004) it varies widely depending upon the sources of protein used in the feed (FontaínhasFernandes et al. 1999). With high quality of protein, teleosts show $95 \%$, or higher, proportion of digestibility (Cho and Kaushik 1990, Anonymous 1993, Regost et al. 2001). Using practical diets, Bairagi et al. (2002) observed $89.46 \%$ protein digestibility of the reference diet $(40 \%$ FM) for the fingerlings of Labeo rohita. Maximum value of protein digestibility $(94.43 \%)$ was obtained by Bairagi et al. (2002) when fish meal was replaced (10\%) by fermented duckweed leaf meal. Full-fat toasted soybean meal showed lower digestibility co-efficient than defatted soybean meal (Fontaínhas-Fernandes et al. 1999) indicating that ingredients containing higher level of fat might result in decreased digestibility of protein. In the presently reported study, the diets containing the FO had a higher level of crude lipid and the average protein digestibility of these diets, although not significantly different, was lower than the reference diet containing only fish meal.

Growth rate of fish increases with increase in the level of dietary protein till the optimum level is reached. Interestingly in the present investigation, the T3 diet having lowest level of dietary protein $(30.2 \%)$ and protein energy ratio $(17.8 \mathrm{mg}$ protein per $\mathrm{kJ})$ of the three diets produced best growth of the fish. Although average intake rate of this diet was significantly higher than the reference diet there is a question if increased intake rate could compensate for the low level of dietary protein. Tilapia fed diets with low protein and energy levels were found unable to compensate by increased rate of intake to

Table 4

Selected water quality parameters recorded during the feeding trial in outdoor tanks

\begin{tabular}{lccc}
\hline \multirow{2}{*}{ Parameter } & \multicolumn{3}{c}{ Treatment (diet) } \\
\cline { 2 - 4 } & $\mathrm{T} 1$ & $\mathrm{~T} 2$ & $\mathrm{~T} 3$ \\
\hline Temperature $\left[{ }^{\circ} \mathrm{C}\right]$ & $22.6 \pm 0.58$ & $22.53 \pm 2.83$ & $21.33 \pm 0.057$ \\
$\mathrm{pH}$ & $7.47 \pm 0.06$ & $7.58 \pm 0.03$ & $7.60 \pm 0.01$ \\
Dissolved oxygen $\left[\mathrm{mg} \cdot \mathrm{L}^{-1}\right]$ & $5.71 \pm 0.14$ & $5.51 \pm 0.47$ & $6.11 \pm 2.14$ \\
Free $\mathrm{CO}_{2}\left[\mathrm{mg} \cdot \mathrm{L}^{-1}\right]$ & $4.09 \pm 0.13$ & $3.52 \pm 0.26$ & $3.37 \pm 0.31$ \\
Alkalinity $\left[\mathrm{mg} \cdot \mathrm{L}^{-1}\right]$ & $197.9 \pm 11.34$ & $190.4 \pm 11.32$ & $200.41 \pm 8.86$ \\
Hardness $\left[\mathrm{mg} \cdot \mathrm{L}^{-1}\right]$ & $190 \pm 3.7$ & $201.87 \pm 8.26$ & $197.91 \pm 10.63$ \\
Total ammonia nitrogen $\left[\mathrm{mg} \cdot \mathrm{L}^{-1}\right]$ & $0.036 \pm 0.01$ & $0.041 \pm 0.01$ & $0.045 \pm 0.01$ \\
\hline
\end{tabular}


achieve comparable growth to fish fed high protein and energy levels (Ali and Jauncey 2004). On the other hand, there is a possibility that increased level of lipid in the diet containing FO might influence sparing of protein. Lipid as a non-protein energy source allows protein sparing by effectively reducing organic matter and nitrogen losses. Protein sparing effects of dietary lipids has been demonstrated for salmonids, sea bass (Cho and Kaushik 1990, Dias et al. 1998), common carp (Manjappa et al. 2002, Gilbey et al. 2001), and grass carp (Du et al. 2005). High level of dietary lipid may lead to deposition of fat in the body of fish and depression of activities of lipogenic enzymes (Arnesen et al. 1993, Alvarez et al. 1998). Little is know about lipogenesis in rohu.

The outcome of the study is that fish offal (FO) can be effectively used as a feed ingredient to replace fish meal partially in the diet for fingerlings of Labeo rohita. Fifty percent replacement of fish meal is possible when $30 \%$ FO is fermented along with MOC and RB (24\% each) and is used as ingredient in the formulated diet.

\section{ACKNOWLEDGEMENTS}

The authors are thankful to Head, Department of Zoology, University of Kalyani for providing necessary facilities for this research.

\section{REFERENCES}

Ali M.Z., Jauncey K. 2004. Effects of feeding regime and dietary protein on growth and body composition in Clarias gariepinus (Burchell, 1822). Indian Journal of Fisheries 51: 407-416.

Ali M.Z., Jauncey K. 2005. Effects of dietary lipid to carbohydrate ratios on body composition, digestive enzyme activities and blood plasma components in African catfish Clarias gariepinus (Burchell, 1822). Journal of Aquaculture in the Tropics 20: 57-70.

Alvarez M.J., López-Bote C.J., Diez A., Corraze G., Arzel J., Dias J., Kaushik S.J., Bautista J.M. 1998. Dietary fish oil and digestible protein modify susceptibility to lipid peroxidation in the muscle of rainbow trout (Oncorhynchus mykiss) and sea bass (Dicentrarchus labrax). British Journal of Nutrition 80: 281-289.

Anonymous 1993. Nutrient requirements of fish. Committee on Animal Nutrition, Board on Agriculture, National Research Council; National Academy Press, Washington DC.

Anonymous 1995. Standard methods for the examination of water and wastewater. American Public Health Association, American Water Works Association and Water Pollution Control Federation, Washington DC.

Arnesen P., Krogdahl A., Kristiansen I.O. 1993. Lipogenic enzyme activities in liver of Atlantic salmon (Salmo salar L.). Comparative Biochemistry and Physiology B 105: 541-546.

Atlas R.M., Parks C.L., Brown A.E. 1995. Laboratory manual of experimental microbiology. Mosby-Year Book Inc., St. Louis.

Bairagi A., Sarkar Ghosh K., Sen S.K., Ray A.K. 2002. Duckweed (Lemna polyrhiza) leaf meal as a source of feedstuff in formulated diets for rohu (Labeo rohita Ham.) fingerlings after fermentation with a fish intestine bacterium. Bioresource Technology 85: 17-24.
Bertsch A., Coello N. 2005. A biotechnological process for treatment and recycling poultry feathers as a feed ingredient. Bioresource Technology 96: 1703-1708.

Bjerkeng B., Refstie S., Fjalestad K.T., Storebakken T., Rødbotten M., Roem A.J. 1997. Quality parameters of the flesh of Atlantic Salmon (Salmo salar) as affected by dietary fat content and full-fat soybean meal as a partial substitute for fish meal in the diet. Aquaculture 157: 297-309.

Bolin D.W., King R.P., Klosterman E.W. 1952. A simplified method for determination of chromic oxide $\left(\mathrm{Cr}_{2} \mathrm{O}_{3}\right)$ when used as an index substance. Science 116: 634-635.

Brafield A.E. 1985. Laboratory studies of energy budgets. Pp. 257-282. In: Tytler P., Calow P. (eds.) Fish energetics: New perspectives. Croom Helm, London.

Castell J.D., Tiews K. 1980. Report of the EIFAC, IUNS and ICES Working Group on the standardization of methodology in fish nutrition research. Hamburg, Germany, 21-23 March. EIFAC Technical Paper 36,

Cho C.Y., Kaushik S.J. 1990. Nutritional energetic in fish: energy and protein utilization in rainbow trout (Salmo gairdneri). World Review of Nutritional Dietetics 61: 132-172.

Dias J., Alvarez M.J., Diez A., Arzel J., Corraze G., Bautista J.M., Kaushik S.J. 1998. Regulation of hepatic lipogenesis by dietary protein/energy in juvenile European seabass (Dicentrarchus labrax). Aquaculture 161: 169-186.

Du Z.-Y., Liu Y.-J., Tian L.-X., Wang J.-T., Wang Y., Liang G.-Y. 2005. Effect of dietary lipid level on growth, feed utilization and body composition by juvenile grass carp (Ctenopharyngodon idella). Aquaculture Nutrition 11: 139-146.

El-Sayed A.-F.M. 1994. Evaluation of soybean meal, Spirulina meal and chicken offal meal as protein sources for silver seabream (Rhabdosargus sarba) fingerlings. Aquaculture 127: 169-176.

Fontaínhas-Fernandes A., Gomes E., Reis-Henriques M.A., Coimbra J. 1999. Replacement of fish meal by plant proteins in the diet of Nile tilapia: digestibility and growth performance. Aquaculture International 7: 57-67.

Garling jr. D.L., Wilson R.P. 1977. Effect of dietary carbohydrate-to-lipid ratio on growth and body composition of fingerling channel catfish. Progressive Fish Culturist 39: 43-47.

Gilbey J., Ali M., Wootton R.J. 2001. Effect of rations of different lipid levels on the growth, food conversion efficiency and lipid contents of the common carp (Cyprinus carpio L.). Pakistan Journal of Zoology 33: 265-269.

Giri S.S., Sahoo S.K., Sahu A.K., Mukhopadhyay P.K. 2000. Nutrient digestibility and intestinal enzyme activity of Clarias batrachus (Linn.) juveniles fed on dried fish and chicken viscera incorporated diets. Bioresource Technology 71: 97-101.

Gomes E.F., Rema P., Kaushik S.J. 1995. Replacement of fish meal by plant protein in the diet of rainbow trout (Oncorhynchus mykiss): digestibility and growth performance. Aquaculture 130: 177-186.

Gomez K.A., Gomez A.A. 1984. Statistical Procedures for Agricultural Research. 2nd edn., John Wiley and Sons, New York. 
Guillou A., Soucy P., Khalil M., Adambounou L. 1995. Effect of dietary vegetable and marine lipid on growth, muscle fatty acid composition and organoleptic quality of flesh of brook charr (Salvelinus fontinalis). Aquaculture 136: 351-362.

Hasan M.R., Macintosh D.J., Jauncey K. 1997. Evaluation of some plant ingredients as dietary protein sources for common carp (Cyprinus carpio L.) fry. Aquaculture 151: 55-70.

Helrich W. (ed.) 1990. Official methods of analyses. Vol. I. 15th edn. Association of Official Analytical Chemists, Washington DC.

Johnson R.A., Wichern D.W. 2005. Applied multivariate statistical analysis. Pearson education of India, Delhi, India.

Kaushik S.J., Cravedi J.P., Lalles J.P., Sumpter J., Fauconneau B., Laroche M. 1995. Partial or total replacement of fish meal by soybean protein on growth, protein utilization, potential estrogenic or antigenic effects, cholesterolemia and flesh quality in rainbow trout, Oncorhynchus mykiss. Aquaculture 133: 257-274.

Kaviraj A., Ghosal T.K. 1998. Effects of compost manure on the body burden of cadmium and growth of common carp Cyprinus carpio (L). Aquaculture Research 29: 555-561.

Manjappa K., Keshavanath P., Gangadhara B. 2002. Growth performance of common carp (Cyprinus carpio) fed varying lipid levels through low protein diet, with a note on carcass composition and digestive enzyme activity. Acta Ichthyologica et Piscatoria 32 (2): 145-15

Mohanty S.N., Swamy D.N., Tripathi S.D. 1990. Growth nutritional indices and carcass composition of Indian major carp fry Catla catla, Labeo rohita and Cirrhinus mrigala fed four dietary protein levels. Aquaculture Hungarica 6: 211-217.

Mondal K., Kaviraj A., Mukhopadhyay P.K. 2006. Fish wastes in urban and sub-urban markets of Kolkata: problems and potentials. Aquaculture Asia 11: 22-25.

Mukhopadhyay P.K., Mitra G. 2007. Plant derived feedstuff for freshwater aquaculture in India. Aquaculture Asia Pacific 3 (6): 15-17.
Pongmaneerat J., Watanabe T., Takeuchi T., Satoh S. 1993. Use of different protein meals as partial or total substitution for fish meal in carp diets. Nippon Suisan Gakkaishi 59: 1249-1257.

Rangacharyulu P.V., Giri S.S., Paul B.N., Yashoda K.P., Rao R.J., Mahendrakar N.S., Mohanty S.N., Mukhopadhyay P.K. 2003. Utilization of fermented silkworm pupae silage in feed for carps. Bioresource Technology 86: 29-32.

Ray A.K., Das I. 1992. Utilization of diets containing composting aquatic weed (Salvinia cuculata) by the Indian major carp, rohu (Labeo rohita, Ham) fingerlings. Bioresource Technology 40: 67-72.

Regost C., Arzel J., Cardinal M., Robin J., Laroche M., Kaushik S.J. 2001. Dietary lipid level, hepatic lipogenesis and flesh quality in turbot (Psetta maxima). Aquaculture 193: 291-309.

Renukardhya K.M., Varghese T.J. 1986. Protein requirement of the carps Catla catla and Labeo rohita (Hamilton). Proceedings of the Indian Academy of Sciences, Animal Science 95: 103-107.

Saha A.K., Ray A.K. 1998. Incorporation of animal by-products in carp diets: Evaluation of poultry litter and goat blood meal as dietary protein sources for rohu (Labeo rohita) fingerlings. Journal of Aquaculture in the Tropics 13: 277-284.

Yang Y., Xie S., Cui Y., Lei W., Zhu X., Yang Y., Yu Y. 2004. Effect of replacement of dietary fish meal by meat and bone meal and poultry by-product meal on growth and feed utilization of gibel carp, Carassius auratus gibelio. Aquaculture Nutrition 10: 289-294.

Received: 18 April 2007

Accepted: 25 November 2007

Published electronically: 15 December 2007 